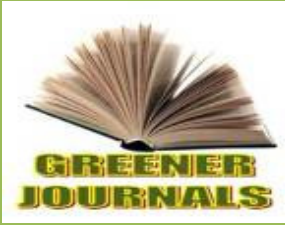

\title{
Determination of Critical Period of Weed- Common Bean (Phaseolus vulgaris L.) Competition at Kaffa, Southwest Ethiopia
}

\section{${ }^{1}$ Tilahun Mola and ${ }^{2 \star K i f l e ~ B e l a c h e w ~}$}

\author{
${ }^{1}$ South Agricultural Research Institute, Bonga Agricultural Research Center, P.O. box 101, Bonga \\ Kaffa, Ethiopia, \\ E-mail: Ot023@yahoo.com \\ ${ }^{2}$ Ethiopian Institute of Agricultural Research, Jimma Agricultural Research Center, P.O.Box 192, \\ Jimma, Ethiopia.
}

Article No.: 030315039

DOI: 10.15580/GJAS.2015.3.030315039

Submitted: 03/03/2015

Accepted: 22/06/2015

Published: 29/06/2015

${ }^{\star}$ Corresponding Author

Kifle Belachew

E-mail: kiflekef@gmail.com

Phone: +251911067034,

$+251471111999$

Keywords:

competition, common bean, critical period, weeds, yield, yield loss
Field experiment was conducted to determine the critical period of weed control in common bean (Phaseolus vulgaris L.) at Bonga Agricultural Research Center, Kaffa zone, Southwestern Ethiopia in 2013/14 cropping season. Two common bean varieties; 'AFR-702' and 'Awassa-dume' were used with two sets of treatments using a randomized complete block design with three replications. In the first set of treatment; the crop was kept weed free until 10, 20, 30, 40, 50 and 60 days after crop emergence (DAE). In the second set; weeds were permitted to grow with in the crop until 10, 20, 30, 40, 50 and 60 DAE. Weedy, weed free, farmers practice and recommended practice were also included in the treatments as control and standard checks.

The weed interference durations affected significantly yield and yield components of both tested common bean varieties. The minimum value of bean yield was observed under the full season weed infestation condition $(7.86 \mathrm{q} / \mathrm{h})$ and $(6.29 \mathrm{q} / \mathrm{h})$ for AFR-702 and Awassa-dume verities respectively. The maximum value of bean yield was recorded from weed free control $(29.84 \mathrm{q} / \mathrm{ha})$ and $(27.2 \mathrm{q} / \mathrm{h})$ for AFR-702 and Awasa-dume varieties respectively. This research result indicated that dry bean yield, 100 seed weights, pod per plant and plant height declined steadily as the duration of weed competition increased. Weed infested conditions for the entire growing season led to common bean yield loss of $73.65 \%$ and $76.88 \%$ for variety AFR-702 and Awassa-dume compared to full-season weed-free treatments respectively.

From this experiment, it is possible to conclude that the critical period of weed competition period for common bean varieties Awassa Dume and AFR-702 lasted when competition exceeds 30 DACE. There for controlling weeds from 10-30 days after crop emergence highly reduce crop weed competition and gives higher bean yield in Kaffa zone of Southwest Ethiopia and similar agroecologies. 


\section{INTRODUCTION}

Common bean (Phaseolus vulgaris L.) is a major source of dietary protein that complements carbohydrate-rich sources such as rice, maize, and cassava. It is also a rich source of dietary fibers, minerals and certain vitamins. The crop is grown worldwide for its edible bean, popular as dry, fresh and green beans. In Ethiopia, common beans are widely cultivated in different agroecologies throughout the country and it covers the largest area. The crop become increasingly important commodity in the cropping systems of smallholder producers for food security and income generation as well as helps in improving soil fertility through biological nitrogen fixation and reduce the dependency on chemical fertilizer input. On the world market, Ethiopia ranks $14^{\text {th }}$ in common bean production and the largest producer among African countries. The country's export earnings from common bean exceed that of other pulses such as lentils, horse bean and chickpea (EASE, 2010). Under the optimal management conditions, productivity of common bean can reach to 2.5 to 3.0 ton per hectare in Ethiopia (Amare, 1987). However, the actual average production from 2008 to 2010 production year is only $1385 \mathrm{~kg}$ per hectare (ICRISAT, 2011) which is very far from the potential yield of the crop. The major production constraints of common beans include biotic and abiotic problems like moisture stress, weeds, diseases, insect pest, soil fertility (Kidane, 1987) and lack of improved seeds (Ayele, 1991). Due to an extreme difference in agro-climatic conditions in the country and cropping practices, common bean production constraints varied from one region to the other. However, weeds are known to be the major factors which threatened the productivity of common bean in high rain fall areas.

Weeds are a permanent constraint to crop productivity in agriculture and they are plants, which compete for nutrients, space, and light; and exert lot of harmful effects by reducing the quality, as well as quantity of the crop, if the weed populations are left uncontrolled (Zuhal et.al., 2010; Nabi et al., 2014) . Rezene and Kedir (2006) pointed out that low land pulses are sensitive to weed competition in the first four weeks after sowing and once timely, early weeding at 25 days after emergence resulted in $70 \%$ yield increase of common bean and up to $300 \%$ increase in cow pea compared to the control. Similar results were also obtained on soyabean (Rezene and kedir, 2006). Common beans compete poorly with weeds as they are low growing plants and do not easily overshadow weeds. Early control is extremely important because the root system of the plant develops at this stage and some weeds secrete chemical substances which limit plant growth.

According to Tilahun (1998), at Jimma, Oromia region of southwestern Ethiopia, two haricot bean varieties, improved "Roba 1" and "Jimma local", required at least two early weeding ( 15 and 30 days after emergence) for efficient weed control, which led to significantly higher crop yields. To reduce the cost and risks of intensive weed control, the frequency or intensity of applications should be reduced or optimized. Critical periods for weed control are defined as the period in the crop growth cycle during, when weeds must be controlled to prevent un-acceptable yield losses (CACC, 2002). In order to provide more precise information for grower's critical periods for weed control should be determined specifically for a particular region by considering the weed composition and climatic conditions (Kidane, 1987). Weed control requires better knowledge of effect of weed competition on crop productivity and the development of tools that can aids farmers' decision about weed control (Kropff and Spitters, 1992).

The critical period is useful in defining the crop growth stages most vulnerable to weed competition. In practice, the critical period is defined as a number of weeks or days after crop emergency during, which a crop must be weed free in order to prevent yield losses greater than 5\% (Hall et al., 1992; Knezevic et al., 1994; Zuhal et.al., 2010; Nabi et al., 2014). The critical period of weed control has been determined for several crops (Shuaib, 2002; Knezevic et al., 2003; Seem et al., 2003; Kavaliauskaite \& Bobinas, 2006; Williams II, 2006; Hamzei et al., 2007; Oad et al., 2007). Common beans are generally cultivated in Kaffa zone of Southwestern Ethiopia. This region has very high rainfall. Because of this, weeds grew up speedily and create great problem in any crop cultivation. However, there is no any information on critical period of common bean in weed competition. There for the objective of this study was to determination of critical period of weed-common bean (Phaseolus vulgaris L.) competition at Kaffa, Southwest Ethiopia.

\section{MATERIALS AND METHODS}

\section{Area description}

The trial was conducted on experimental site of Bonga agricultural research center during 2013/14 cropping season southwestern Ethiopia. The center is located "Kiakela" peasant association at Gimbo district of Kaffa zone, Southern Nations Nationalities and People's Region (SNNPR). It is found within the southwestern plateau of Ethiopia and $8 \mathrm{~km}, 450 \mathrm{~km}$ and $725 \mathrm{~km}$ far from zonal town Bonga, Federal city Addis Ababa and regional city Hawassa respectively. The area lies at $07^{\circ} 16^{\prime} 48^{\prime \prime} \mathrm{N}$ Latitude and $036^{\circ} 14^{\prime} 25^{\prime \prime}$ E Longitude at the altitude of 1860 masl. The area experiences one long rainy season, lasting from March or April to October. The mean annual rainfall ranges from $1710 \mathrm{~mm}$ to $2000 \mathrm{~mm}$. Over $85 \%$ of the total annual rainfall, with mean monthly values in the range of $125-250 \mathrm{~mm}$ occurs in the 8 months long rainy season. The mean temperature ranges from $18.1^{\circ} \mathrm{C}$ to $21.4^{\circ} \mathrm{C}$. Environmentally the site is belongs to the sub-agro ecology tepid to midland and 
comprising of mixed arable farming and woodland, including much relict primary tropical forest. The soil of the study area is sandy clay loam at the top and sandy clay at sub soil characterized as "dystric nitosol" with ph of 5.4. The topography is characterized by slopping and rugged areas with very little plain land (WBISPP, 2001; Cherinet, 2008).

\section{Experimental materials and design}

Common bean varieties 'AFR-702' and 'Awassa Dume' with recommended all agronomic practices were used for this experimental study. The research design was randomized complete block design (RCBD) with three replications for each common bean variety. Total area for this experiment was $9 \times 34.6 \mathrm{~m}^{2}$ with single plot size of $1.6 \mathrm{~m} \times 2 \mathrm{~m}$, and gangway between block $1.5 \mathrm{~m}$ and plot $0.6 \mathrm{~m}$. The spacing used was $40 \mathrm{~cm}$ by $10 \mathrm{~cm}$ between row and plants respectively. Total treatments are two sets of experiment (weed interference and weed control) in addition four controls checks weed free control, weedy control, recommended practice and farmers practice were used (Table 1). Rainfall is used as a source of water. Two days before each weed removal, weeds were harvested from $0.5 \mathrm{~m}^{2}$ quadrants/plot. In weed free plots weeds were removed manually at any time if necessary. Weed density of different weed species were collected and taken to laboratory after $60 \mathrm{DAE}$.

Table 1: Descriptions of treatments

\begin{tabular}{|c|c|}
\hline $\begin{array}{l}\text { Set one } \\
\text { Weed infested period } \\
\text { (Interference Treatments) }\end{array}$ & $\begin{array}{c}\text { Set two } \\
\text { Weed free period } \\
\text { (Control Treatments) }\end{array}$ \\
\hline Weed infestation $10 \mathrm{DAE}$ & Weeding $10 \mathrm{DAE}$ \\
\hline Weed infestation 20 DAE & Weeding 20 DAE \\
\hline Weed infestation $30 \mathrm{DAE}$ & Weeding 30 DAE \\
\hline Weed infestation $40 \mathrm{DAE}$ & T-12 Weeding 40 DAE \\
\hline Weed infestation $50 \mathrm{DAE}$ & T-13 Weeding 50 DAE \\
\hline Weed infestation $60 \mathrm{DAE}$ & Weeding $60 \mathrm{DAE}$ \\
\hline T-7 Weedy control ( WC)* & Weed free control( WF $)^{*}$ \\
\hline T-8 Farmers Practice( FP)* & Recomended practice $(\mathrm{RP})^{*}$ \\
\hline
\end{tabular}

\section{Data collection and analysis}

All relevant data were collected like plant height $(\mathrm{cm})$, number of pods/plant, pod length $(\mathrm{cm})$, dry bean yield $(\mathrm{kg}), 100$ seed weight $(\mathrm{gm})$ and yield loss due to weed interference. Accordingly; additional data of number of days from emergence to flowering and number of days from emergence to maturity were recorded. At maturity, ten plants were randomly selected from each plot and tagged as the above data sources. Flowering date was recorded when $75 \%$ of plants in the plot reached flowering stage; whereas, maturity date was recorded when $95 \%$ of the plant in the plot turned to brown. At maturity the crop was harvested, threshed, air dried and weighed. Moreover, weed density as well as individual weed species population count were recorded. Finally yield loss was estimated using the following formula.

$\begin{aligned} & \text { Yield loss }(\%)= \\ & \text { (yield of treated plot) }\end{aligned}$
free plot)

All measured variables were subjected to analysis of variance using general linear model procedure of SAS software (SAS Institute, 2000).

\section{RESULTS AND DISCUSSIONS}

The major weeds species found in experimental plots were Galinsoga parviflora, Bidense biternata, Bidense pilosa, Amarehanthus species, Commelina latifolia, Cuscuta campestris, Rumex abyssinicus, Polygonum nepalense, and Hibiscus trionum. These weed species are common in pulse crops grown around the study area while Cuscuta campestris is the most dangerous parasitic weed which can affect the pulse crops in greater extent and difficult to control. The Previous results for the major weeds in common bean around southwest Ethiopia have been similar (Tilahun, 1998).

The analysis variance clearly showed that the impact of interference weed periods on all of the traits were significantly different in two common bean varieties "Awassa Dume" and "AFR-702" ( $P<0.01$, Table 2 and $3)$. Reduction in seed yield caused by the increased length of weed interference period, was associated by contemporary diminish in pod number in plant, seed in pod, 100 grain weight, bean yield and total dry matter (Table 4). A similar result were reported on chickpea by Al-Thahabi et al. (1994), Rashid et al. (2009), Tepe et al. (2011) and Fathi et al. (2011) where weed interference decreased simultaneously number of pod per plant and 100 grain weight. Conversely, the beneficial effect of 
reduced weed competition show on pod in plant, seed in pod, 100 grain weight, and total dry matter, which is ultimately reflected in seed yield. Weed infested conditions for the entire growing season led to 76.4$85.8 \%$ and $78.5-85.7 \%$ reduction in chickpea dry matter and seed yield compared with full-season weed-free treatments. Similarly in this experiment the beneficial effect of reduced weed competition seen on plant height, number of pods in plant, number of seeds in pod, 100 grain weight, dry bean yield and total dry matter of common bean, which is ultimately reflected in total dry bean yield. Weed infested conditions for the entire growing season led to $76.88 \%$ reduction in total dry bean yield of Awassa dume variety common bean compared with full-season weed-free treatment (Table 4).

The analysis of variance indicated that there was a significantly difference at $p<0.05$ among different weeding period or control treatments on "Awassa Dume" common bean variety on yield and yield components. Weed control period have shown effect on plant height, number of pods per plant, pod length, 100 seed weight and actual yield per hectare of common bean. In "Awassa Dume" variety weed free control treatment scored the highest dry bean yield (27.2 qt/ha) and significantly different from weedy control treatment $(6.29 \mathrm{qt} / \mathrm{ha})$ which give the lowest dry bean yield. Common bean yield loss due to weed interference was $76.88 \%$ compared to weed free control on "Awassa Dume" variety. More over weed interference treatments shows significant difference in all common bean traits on "Awassa Dume" variety (Table 4). Allowing weed interference 10 days after crop emergence $(14.87 \mathrm{q} / \mathrm{ha})$ gives significantly lower yield than allowing 60 days after crop emergence (24.46 q/ha) (Table 4). In the same way weed control treatments shows significant difference in all common bean traits on "Awassa Dume" variety (Table 4). Controlling weeds 10 days after crop emergence $(25.57 \mathrm{Q} / \mathrm{ha})$ gives significantly higher yield than controlling weeds 60 days after crop emergence $(15.9 \mathrm{Q} / \mathrm{ha})$ (Table 4). Here it is possible to determine that early season weed interference result is comparable to late weed control and early growing stage weed control is comparable to late growth stage weed interference. Thus early growth stage weed computation significantly reduces common bean yield in "Awassa Dume" variety (Table 4).

The highest plant height $(74.77 \mathrm{~cm})$ was observed in weed free control of "Awassa Dume" variety while the shortest height $(36.84 \mathrm{~cm})$ noticed in weedy control. Similarly weed controlling $10 \mathrm{DAE}$ treatment gives higher height $(69.94 \mathrm{~cm})$ compared to controlling weeds 60 DAE treatment $(44.84 \mathrm{~cm})$ in this variety (Table 4). There was significantly different result was observed in weed free treatment pod per plant (58.35), pod length $(11.79 \mathrm{~cm}), 100$ seed weight $(37.48 \mathrm{gm})$ and dry yield $(27.2 \mathrm{q} / \mathrm{ha})$ compared to weedy control (13.35), (7.79 $\mathrm{cm}),(29.78 \mathrm{gm})$ and $(6.29 \mathrm{q} / \mathrm{ha})$ of pod per plant, pod length, seed weight and dry bean yield respectively in "Awassa Dume" variety (Table 4).

Analysis of variance indicated that there was a significantly difference at $p<0.05$ among weeding time on "AFR-702" variety on yield and yield components. Weed control and interference period have shown effect on plant height, number of pods per plant, pod length, 100 seed weight and actual yield per hectare. In "AFR702" variety weed free control treatment scored the highest dry bean yield (29.84 qt/ha) and significantly different from weedy control treatment (7.86 q/ha) which give the lowest dry bean yield. Bean yield loss due to weed interference in "AFR-702" variety was $73.65 \%$ compared to weed free control. More over weed interference treatments shows significant difference in all common bean traits "AFR-702" variety (Table 5). Allowing weed interference 10 days after crop emergence $(12.9 \mathrm{Q} / \mathrm{ha}$ ) gives lower yield than allowing 60 days after crop emergence (26.27 Q/ha) (Table 5). In the same way weed control treatments shows significant difference in all common bean traits of "AFR-702" variety (Table 5). Controlling weeds 10 days after crop emergence (28.83 Qt/ha) gives higher yield than controlling weeds 60 days after crop emergence (17.94 $\mathrm{Qt} / \mathrm{ha}$ ) (Table 5). Here also it is possible to determine that early season weed interference result is comparable to late weed control and early growing stage weed control is comparable to late growth stage weed interference. Thus early growth stage weed competition significantly reduces common bean yield in "AFR-702" variety (Table 5).

The highest plant height $(130.10 \mathrm{~cm})$ was observed in weed free control of "AFR-702" variety while the shortest height $(76.10 \mathrm{~cm})$ noticed in weedy control. Similarly weed control 10 DAE treatment gives higher height $(119.33 \mathrm{~cm})$ compared to controlling weeds 60 DAE treatment $(82.10 \mathrm{~cm})$ in "AFR-702" variety (Table 5). Moreover, there was significantly different result was observed in weed free treatment on pod per plant (42.33), pod length $(16.10 \mathrm{~cm}), 100$ seed weight $(35.73$ $\mathrm{gm})$ and dry bean yield (29.84 q/ha) compared to weedy control (18.33), (14.27 cm), (29.35 gm) and (7.86 q/ha) of pod per plant, pod length, seed weight and dry bean yield respectively in "AFR-702" variety (Table 5). In other studies twice hand weeding applied during 15-45 days after crop emergence is recommended for verification in Mexican-142 common bean variety, whereas one early weeding applied during $20-25$ days after crop emergence in two other apparently more competitive varieties Ex-Rico and Red woliata for the central rift valley areas were recommended (Abriham et. al., 2008). In Jimma area, of southwestern Ethiopia twice hand weeding applied during (15-30 days after crop emergence) is recommended for weed control verification for two haricot bean varieties: Roba 1 (improved) and Jimma local (Tilahun, 1998). This trial also found somewhat similar result to the above recommendations. 
Table 2: Analysis variance of square means of the traits under different weed-free and weed -infested (interference) treatments "Awassa Dume" Variety

\begin{tabular}{|c|c|c|c|c|c|c|}
\hline $\begin{array}{l}\text { Source } \\
\text { Of variation }\end{array}$ & $d f$ & $\begin{array}{c}\text { Plant height } \\
(\mathrm{cm})\end{array}$ & Pod /plant & $\begin{array}{l}\text { Pod length } \\
\text { (cm) }\end{array}$ & $\begin{array}{c}100 \text { seed wt } \\
(\mathrm{gm})\end{array}$ & Dry Yield (q/h) \\
\hline \multicolumn{7}{|c|}{ Interferences } \\
\hline Rep & 2 & ns 37.20 & ns1.30 & ${ }^{\mathrm{ns}} 0.63$ & *19.85 & ns3.84 \\
\hline Trt & 9 & *236.00 & ns 173.81 & *2.43 & *31.37 & *274.36 \\
\hline Error & 18 & 18.02 & 78.41 & 0.97 & 5.33 & 8.39 \\
\hline $\mathrm{CV}$ & & 15.66 & 30.85 & 6.57 & 6.94 & 12.62 \\
\hline \multicolumn{7}{|c|}{ Control } \\
\hline Rep & 2 & ns2.71 & ns 37.20 & ns 2.02 & *15.91 & ns 30.44 \\
\hline Trt & 9 & *816.23 & *236.01 & ns 1.42 & *15.49 & *298.397 \\
\hline Error & 18 & 42.39 & 18.01 & 1.35 & 3.61 & 8.06 \\
\hline $\mathrm{CV}$ & & 16.42 & 15.66 & 7.72 & 5.63 & 9.66 \\
\hline
\end{tabular}

Note, df, degree of freedom; Rep, replication; trt, treatments; CV, coefficient of variation

Table 3: Analysis variance of for means of square of the traits under different weed-freed and weed -infested (interference) treatments “AFR-702” Variety

\begin{tabular}{|c|c|c|c|c|c|c|}
\hline Variable & $d f$ & $\begin{array}{l}\text { Plant height } \\
\text { (cm) }\end{array}$ & Pod /plant & $\begin{array}{l}\text { Pod length } \\
\text { (cm) }\end{array}$ & $\begin{array}{l}100 \text { seed wt } \\
(\mathrm{gm})\end{array}$ & Dry Yield (q/h) \\
\hline & \multicolumn{6}{|c|}{ Interferences } \\
\hline Rep & 2 & ${ }^{n s} 69.40$ & ns2.85 & ns 0.92 & ns 3.15 & ns5.86 \\
\hline Trt & 9 & *379.39 & *541.86 & *5.02 & *26.06 & *207.95 \\
\hline Error & 18 & 47.49 & 8.61 & 0.54 & 1.91 & 15.98 \\
\hline \multirow[t]{2}{*}{ CV } & & 12.63 & 8.01 & 7.49 & 14.03 & 14.47 \\
\hline & \multicolumn{6}{|c|}{ Control } \\
\hline Rep & 2 & ns93.11 & ns16.92 & $\mathrm{ns}^{\mathrm{ns}} 0.48$ & *41.22 & ns11.48 \\
\hline Trt & 9 & *388.66 & ${ }^{*} 536.42$ & *4.46 & ${ }^{\star} 21.45$ & ${ }^{*} 230.25$ \\
\hline Error & 18 & 46.10 & 14.78 & 0.67 & 3.49 & 19.89 \\
\hline $\mathrm{CV}$ & & 14.85 & 10.71 & 8.33 & 15.482 & 16.77 \\
\hline
\end{tabular}

Note:- df, degree of freedom; Rep, replication; trt, treatments; CV, coefficient of variation

Table 4. Means values of the traits under different weed-free (control) and weed -infested treatments (interference) at "Awassa Dume" variety

\begin{tabular}{|c|c|c|c|c|c|c|}
\hline \multicolumn{7}{|c|}{ Table 1 Awassa Dume } \\
\hline Treatments & $\begin{array}{l}\text { Plant height } \\
\text { (cm) }\end{array}$ & Pod /plant & Pod length $(\mathrm{cm})$ & $\begin{array}{l}100 \text { seed } \\
\text { wt }(\mathrm{gm})\end{array}$ & $\begin{array}{l}\text { Dry Yield } \\
(\mathrm{q} / \mathrm{h})\end{array}$ & $\begin{array}{l}\text { Yield } \\
\text { loss } \%\end{array}$ \\
\hline \multicolumn{7}{|c|}{ Interferences } \\
\hline $\mathrm{T}-1$ & 42.94 & 23.68 & 8.62 & 30.45 & 14.87 & 45.34 \\
\hline T-2 & 45.84 & 29.68 & 9.45 & 33.05 & 17.02 & 37.42 \\
\hline $\mathrm{T}-3$ & 49.24 & 32.68 & 9.79 & 33.35 & 19.08 & 29.88 \\
\hline T-4 & 54.84 & 39.68 & 10.62 & 36.38 & 21.20 & 22.07 \\
\hline $\mathrm{T}-5$ & 60.24 & 44.68 & 10.79 & 36.35 & 22.71 & 16.52 \\
\hline T-6 & 65.54 & 51.68 & 10.95 & 37.25 & 24.48 & 10.02 \\
\hline $\mathrm{T}-7$ (WC) & 36.84 & 13.35 & 7.79 & 29.78 & 6.29 & 76.88 \\
\hline $\mathrm{T}-8(\mathrm{FP})$ & 54.74 & 29.98 & 9.45 & 32.05 & 18.62 & 31.53 \\
\hline $\mathrm{T}-15(\mathrm{WF})$ & 74.47 & 58.35 & 11.79 & 37.48 & 27.20 & 0.00 \\
\hline $\mathrm{T}-16(\mathrm{RP})$ & 60.50 & 42.58 & 8.62 & 37.15 & 21.90 & 19.50 \\
\hline $\operatorname{LSD}(0.05)$ & 11 & 6.60 & 1.27 & 3.21 & 7.65 & \\
\hline \multicolumn{7}{|c|}{ Control treatments } \\
\hline T-9 & 69.94 & 50.35 & 10.95 & 35.71 & 25.57 & 5.98 \\
\hline $\mathrm{T}-10$ & 65.50 & 43.68 & 10.79 & 36.75 & 23.82 & 12.44 \\
\hline $\mathrm{T}-11$ & 59.74 & 37.68 & 10.22 & 34.75 & 23.57 & 13.34 \\
\hline $\mathrm{T}-12$ & 56.04 & 31.68 & 9.79 & 33.75 & 19.20 & 29.43 \\
\hline $\mathrm{T}-13$ & 50.54 & 28.68 & 9.54 & 32.15 & 16.60 & 38.96 \\
\hline $\mathrm{T}-14$ & 44.84 & 22.68 & 9.22 & 31.48 & 15.19 & 44.14 \\
\hline $\mathrm{T}-7(\mathrm{WC})$ & 36.84 & 13.35 & 7.79 & 29.78 & 6.29 & 76.88 \\
\hline $\mathrm{T}-8(\mathrm{FP})$ & 54.74 & 29.98 & 8.32 & 32.05 & 18.62 & 31.53 \\
\hline $\mathrm{T}-15(\mathrm{WF})$ & 74.47 & 58.35 & 11.79 & 37.48 & 27.20 & 0.00 \\
\hline $\mathrm{T}-16(\mathrm{RP})$ & 60.50 & 42.58 & 10.43 & 37.15 & 21.90 & 19.50 \\
\hline $\operatorname{LSD}(0.05)$ & 11.81 & 5.04 & .41 & & 6.86 & \\
\hline
\end{tabular}

Note: DAE, days after crop emergence; WF, weed free in growing period; WC, weedy control or weed interfered in all growing period; RP, recommended practice; FP, farmers practice; LSD, least significant difference $\mathrm{P}<5 \%$. 
Table 5. Means values of the traits under different weed-free (control) and weed -infested (interference) treatments at "AFR-702" variety

\begin{tabular}{|c|c|c|c|c|c|c|}
\hline $\begin{array}{l}\text { Treatments } \\
\text { (DAE) }\end{array}$ & $\begin{array}{l}\text { Plant } \\
\text { height } \\
\text { (cm) }\end{array}$ & Pod /plant & $\begin{array}{l}\text { Pod length } \\
(\mathrm{cm})\end{array}$ & $\begin{array}{l}100 \\
\text { seed wt } \\
(\mathrm{gm})\end{array}$ & $\begin{array}{l}\text { Dry } \\
\text { Yield } \\
(\mathrm{q} / \mathrm{h})\end{array}$ & $\begin{array}{l}\text { Yield loss } \\
\text { (\%) }\end{array}$ \\
\hline \multicolumn{7}{|c|}{ Interferences } \\
\hline $\mathrm{T}-1$ & 119.33 & 23.00 & 14.63 & 29.01 & 12.90 & 56.76 \\
\hline T-2 & 112.43 & 26.67 & 14.97 & 30.03 & 15.91 & 46.67 \\
\hline T-3 & 101.43 & 27.67 & 15.20 & 31.47 & 18.57 & 37.76 \\
\hline $\mathrm{T}-4$ & 95.10 & 27.67 & 15.13 & 35.61 & 21.16 & 29.08 \\
\hline $\mathrm{T}-5$ & 90.77 & 27.67 & 14.93 & 36.13 & 23.68 & 20.63 \\
\hline $\mathrm{T}-6$ & 82.10 & 41.67 & 16.17 & 36.81 & 26.27 & 11.95 \\
\hline $\mathrm{T}-7(\mathrm{WC})$ & 76.10 & 18.33 & 14.27 & 29.35 & 7.86 & 73.65 \\
\hline T-8 (FP) & 100.43 & 24.33 & 14.03 & 31.61 & 20.30 & 31.96 \\
\hline T-15(WF) & 130.10 & 42.33 & 16.10 & 35.73 & 29.84 & 0.00 \\
\hline $\mathrm{T}-16(\mathrm{RP})$ & 105.33 & 27.67 & 15.26 & 36.71 & 27.67 & 7.26 \\
\hline LSD (0.05) & 7.28 & 15.19 & 1.99 & 3.96 & 4.87 & \\
\hline \multicolumn{7}{|c|}{ Control Treatment } \\
\hline T-9 & 90.77 & 36.00 & 15.66 & 34.89 & 28.83 & 3.39 \\
\hline $\mathrm{T}-10$ & 95.10 & 24.67 & 15.24 & 34.36 & 27.81 & 6.79 \\
\hline $\mathrm{T}-11$ & 98.77 & 24.67 & 14.87 & 35.02 & 25.85 & 13.36 \\
\hline $\mathrm{T}-12$ & 98.10 & 21.00 & 14.50 & 34.36 & 22.70 & 23.92 \\
\hline $\mathrm{T}-13$ & 95.10 & 23.33 & 14.23 & 31.59 & 20.81 & 30.25 \\
\hline T-14 & 121.43 & 19.33 & 14.16 & 30.26 & 17.94 & 39.87 \\
\hline T-7(WC) & 81.43 & 16.00 & 13.83 & 30.58 & 7.86 & 73.65 \\
\hline $\mathrm{T}-8(\mathrm{FP})$ & 97.43 & 28.00 & 15.03 & 33.41 & 20.30 & 31.96 \\
\hline T-15(WF) & 119.10 & 46.00 & 16.77 & 36.68 & 29.84 & 0.00 \\
\hline$T-16(\mathrm{RP})$ & 107.33 & 32.00 & 15.86 & 36.45 & 27.67 & 7.26 \\
\hline LSD (0.05) & 11.17 & 7.28 & 1.69 & 3.26 & 4.97 & \\
\hline
\end{tabular}

Note: DAE, days after crop emergence; WF, weed free in growing period; WC, weedy control or weed interfered in all growing period; RP, recommended practice; FP, farmers practice; LSD, least significant difference $\mathrm{P}<5 \%$.

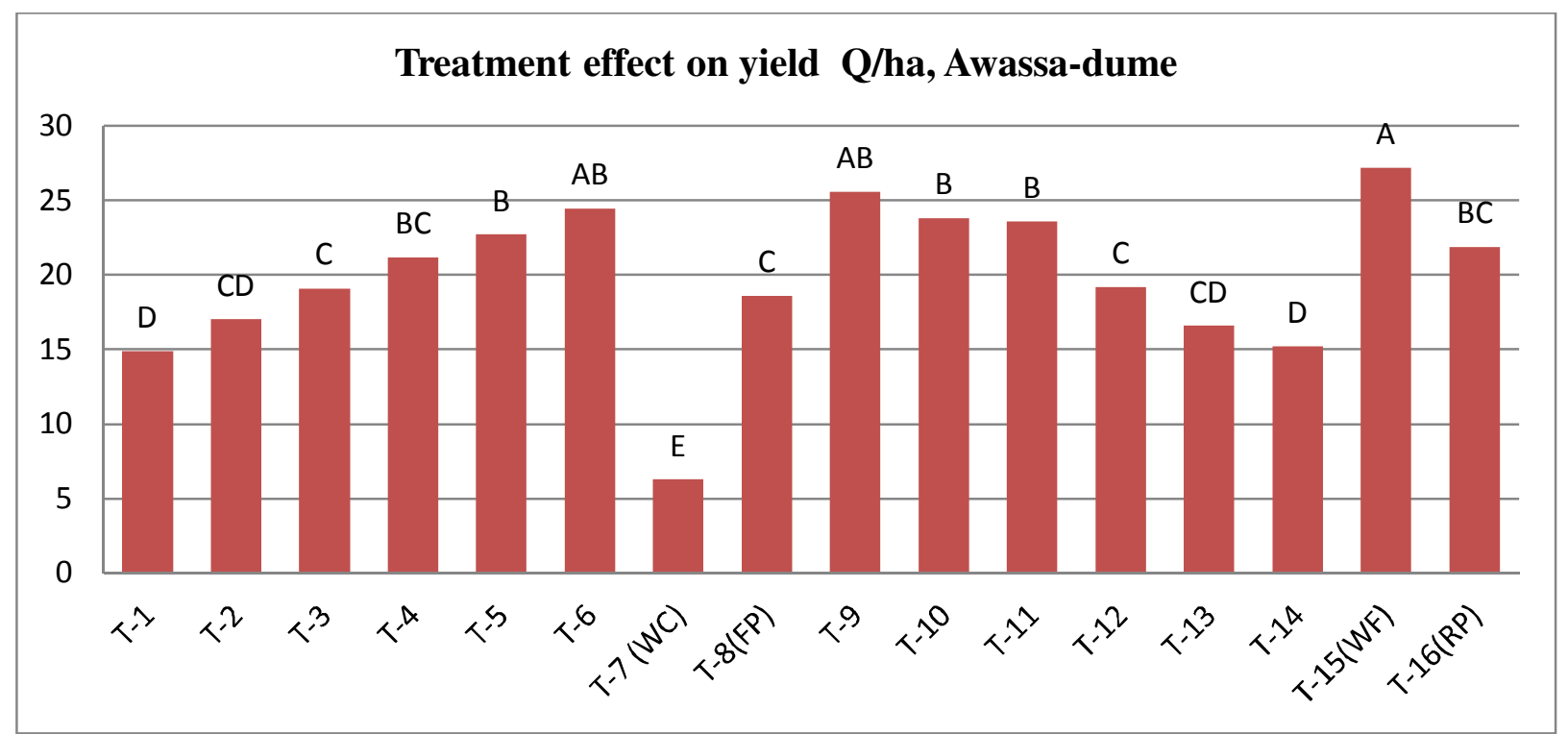

Figure1: Effect of different weeding treatment on yield of common bean of "Awassa Dume" variety 


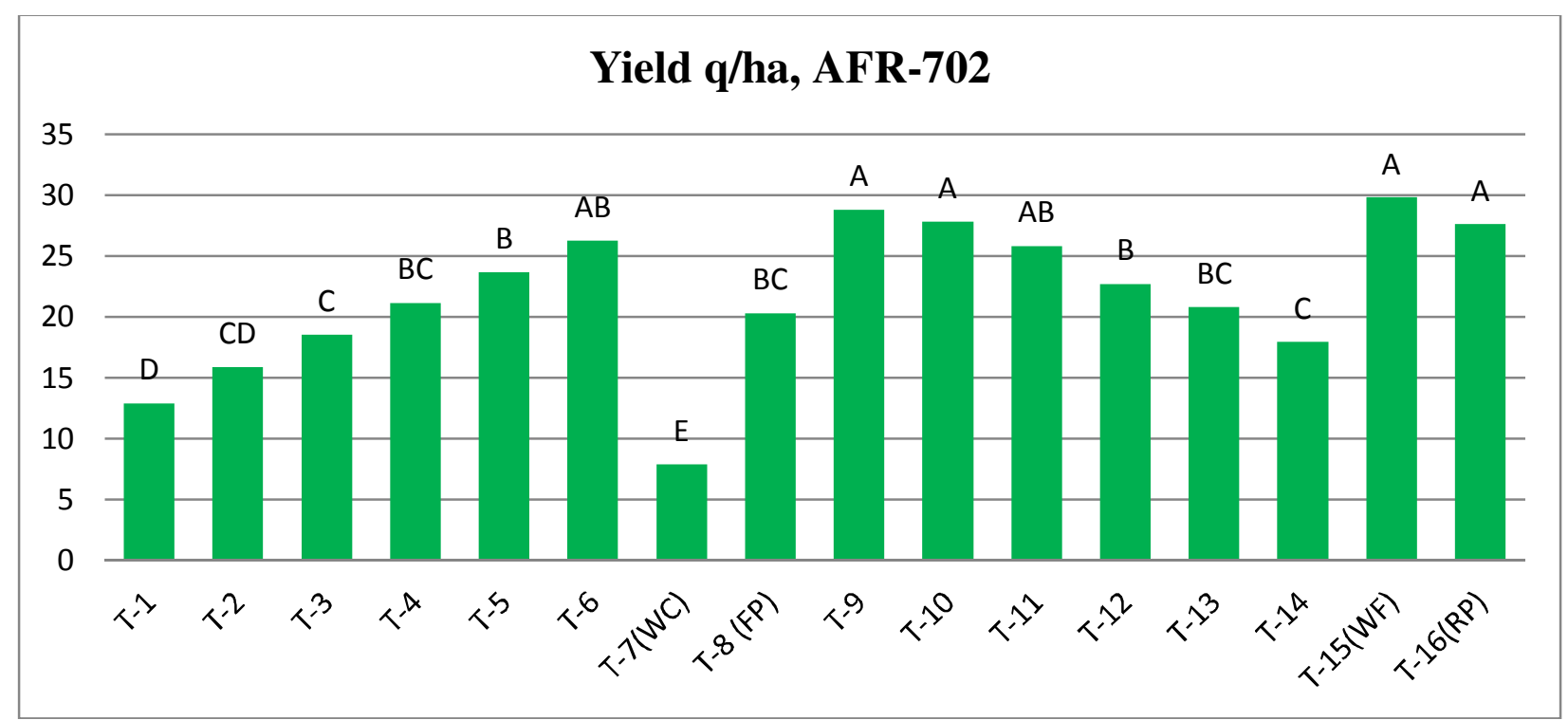

Figure 2: Effect of different weeding treatments on yield of common bean of "AFR-702" variety

\section{CONCLUSION}

Weeds are a permanent constraint to crop productivity in agriculture and common beans compete poorly with weeds as they are low growing plants and do not easily overshadow weeds. Weed control requires better knowledge of effect of weed competition on crop productivity and the development of tools that can aids farmers' decision about weed control. In order to provide more precise information for grower's critical periods for weed control should be determined specifically for a particular region by considering the weed composition and climatic conditions.

The critical period is useful in defining the crop growth stage most vulnerable to weed competition. This trial result indicated that it is possible to get about 25.57 $\mathrm{q} / \mathrm{ha}$ and $28.83 \mathrm{q} / \mathrm{ha}$ by controlling weed competition at early stage; ten days after crop emergency prior to recommended weeding time as 3-6 weeks after crop emergence $21.9 \mathrm{q} / \mathrm{ha}$ and $27.67 \mathrm{~g} / \mathrm{ha}$ from Awassa dume and "AFR-702" varieties respectively.

In conclusion, the result of this experiment showed that the critical period of weed for common bean varieties Awassa Dume and AFR-702 lasted when competition exceeds 30 DACE. There for controlling weeds from 10-30 days after crop emergence highly reduce crop weed competition and gives higher bean yield in Kaffa zone of Southwest Ethiopia and similar agro-ecologies. This result is similar to national recommendation 3-6 weeks or 21 - 42 days after crop emergence but earlier by one week.

\section{ACKNOWLEDGEMENTS}

The authors would like to acknowledge South Ethiopian Institute Agricultural Research, Bonga Agricultural
Research Center for providing fund, field and facilities. Moreover, authors acknowledge all staffs of Bonga Agricultural Research Center members. Special thanks also go to Mr. Minyahil Kebede, Mr. Abate G/Michael and Ms. Aminat Hasen of crop protection division team for the field work and data collection.

\section{REFERENCES}

Abraham Tadesse, Rezene Fessehaie and Kedir Nesro (2008). Review of weed research in high lands and lowland pulses volume 1. Abraham Tadesse (ed), Proceedings of the $14^{\text {th }}$ annual conference of plant protection society of Ethiopia (PPSE). Pp 133-165. Date 19-22 December 2006, PPSE and EIAR, Addis Abeba, Ethiopia.

Al-Thahabi SA, Yasin JZ, Abu-Irmaileh BE, Haddad NI, Saxena MC. (1994). Effect of weed removal on productivity of chickpea and lentil in a Mediterranean environment. Journal of Agronomy and Crop Science 5, 333-341.

Amare, (1987). Haricot bean (Phaseolus vulgaris L.) varieties performance and recommended methods of production. pp. 229-251 In: Proceedings of the 19th National Crop Improvement Conference, Institute of Agricultural Research, Addis Ababa, Ethiopia.

Ayele, H. (1991). Importance of haricot bean export to the Ethiopian economy. pp 31- 34 In: Research on haricot bean in Ethiopia: an assessment of status, progress, priorities and strategies, 1-3 October, 1990. Addis Ababa, Ethiopia.

Central agricultural census commission (CACC) (2002). Ethiopian agricultural sample Enumeration, 2001/2002: report on the primary result of area, production and yield of temporary crops (Meher 
season private peasant holding) part 1. Addis Abeba.

Chernet, T. (2008). Land Resources and SocioEconomic Report of Bonga, Boginda, Mankira and the Surrounding Areas in Kaffa Zone, SNNPRS, Ethiopia [WWW document]. URL http://www.kafabiosphere. com/assets/contentdocuments/KafaLand-use-Survey- Final-Report.pdf [accessed on 13 January 2015].

EASE (Ethiopian Agricultural Sample Enumeration) (2003). Statistical report on area and production of crops results for SNNPR. Pp. 519. Part 2, Addis Ababa, Ethiopia.

Fathi AOE, Khalaf AS, Salim NM. (2010). Influence of tillage and weed management methods on chickpea yield and yield components, Plakistan Journal of weed Science 16(2), 189-198.

Hall, M.R., C.J. Swanton and G.W. Anderson, (1992). The critical period of weed control in grain corn (Zea mays). Weed Sci., 40: 441-447.

Hamzei, J., A.D.M. Nasab, F.R. Khoie, A. Javanshir and M. Moghaddam, (2007) Critical period for weed control in three oilseed rape (Brassica napus L.) cultivars. Turky J. Agric. For., 31: 83-90.

Kavaliauskaite, D. and C. Bobinas, (2006). Determination of weed competition critical period in red beet. Agron. Res., 4: 217-220.

Kidane, G. (1987). A review of bean agronomy research in semi-arid regions of Ethiopia. Pp 174-180 In: Proceedings of bean research in Eastern Africa. Mukono, Uganda, 22-25 June 1987.

Knezevic SZ, Horak MJ, Vanderlip RL. (1997). Relative time of redroot pigweed (Amaranthus retroflexus) emergence is critical in pigweed-sorghum (Sorghum bicolor) competition. Weed Science 45, 502-508.

Knezevic, S.Z., S.P. Evans, E.E. Blankenship, R.C. Van Acker and J.L. Lindquist, (2002). Critical period for weed control: The concept and data analysis. Weed Sci., 50: 773-786.
Kropff, M.J., Lotz, L.A.P., Weaver, S.E. (1993). Practical applications modeling crop-weed interactions. In: KROPFF, M.J.; VAN LAAR, H.H. (Eds.). Wallingford, UK. CAB International, 1993. p.149-167.

Oad, F.C., M.H. Siddiqui and U.A. Buriro, (2007). Growth and yield losses in wheat due to different weed densities. Asian J. Plant Sci., 6: 173-176

Rashid A, Khan R, Marwat S. (2009). Importance of weed contrl in chickpea under rainfed condition, American-Eurasian Journal of Agriculture and Environment Science 5(4), 456-459.

Rezene Fessehaie and Kedir Nesro. (2008). Review of weed research in high lands and lowland pulses volume 1. Abraham Tadesse (ed), Proceedings of the $14^{\text {th }}$ annual conference of plant protection society of Ethiopia (PPSE). Pp 123-133. Date 19-22 December 2006, PPSE and EIAR, Addis Abeba, Ethiopia.

SAS Inst., (2000). Statistical Analysis Systems Institute Inc. Version 9. Cary, North Carolina.

Seem, J.E., N.G. Cramer and D.V. Monks, 2003. Critical weed-free period for 'Beauregard' sweet potato (Ipomea batatas). Weed Technol., 17: 686-695

Shuaib, O.S.B., 2002. Critical period for weed competition in onions (Allium cepa L.). University Aden J. Appl. Sci., 5: 355-360.

Tepe I, Erman M, Yergin R, Bukun B. 2011. Critical period of weed control in chickpea under nonirrigated conditions, Turk Journal of Agriculture and Forestry 35, 525-534.

Tilahun tedious. 1998. Weed competition study on haricot bean in the sub-humid zone of jimma. Arem: pp 61-68.

WBISPP, 2001. SNNPRS - a strategic plan for the sustainable development, conservation, and management of the woody biomass resources, final report, Addis Abeba biology, 12; 318-320

Williams II, M.M., 2006. Planting date influences critical period of weed control in sweet corn. Weed Sci., 54: 928-933. 